\title{
Modifications Caused by Enzyme-Retting and Their Effect on Composite Performance
}

\author{
Jonn A. Foulk, ${ }^{1}$ Denis Rho, ${ }^{2}$ Mercedes M. Alcock, ${ }^{3}$ Chad A. Ulven, ${ }^{4}$ and Shanshan Huo ${ }^{5}$ \\ ${ }^{1}$ CQRS, ARS, USDA, Ravenel Center Room 10, McGregor Road, Clemson, SC 29634, USA \\ ${ }^{2}$ Biotechnology Research Institute, National Research Council Canada, 6100 Royalmount Avenue, Montreal, QC, Canada H4P 2R2 \\ ${ }^{3}$ Composites Innovation Centre, Product Innovation, 300-78 Innovation Drive, Winnipeg, MB, Canada R3T 6C2 \\ ${ }^{4}$ Department of Mechanical Engineering, North Dakota State University, Dolve Hall 103, Fargo, ND 58105, USA \\ ${ }^{5}$ Department of Mechanical Engineering, North Dakota State University, Dolve Hall 111, Fargo, ND 58105, USA
}

Correspondence should be addressed to Jonn A. Foulk, jonn.foulk@ars.usda.gov

Received 15 March 2011; Accepted 14 July 2011

Academic Editor: H. P. S. Abdul Khalil

Copyright (C) 2011 Jonn A. Foulk et al. This is an open access article distributed under the Creative Commons Attribution License, which permits unrestricted use, distribution, and reproduction in any medium, provided the original work is properly cited.

\begin{abstract}
Bethune seed flax was collected from Canada with seed removed using a stripper header and straw pulled and left in field for several weeks. Unretted straw was decorticated providing a coarse fiber bundle feedstock for enzyme treatments. Enzyme treatments using a bacterial pectinolytic enzyme with lyase activity were conducted in lab-scale reactors. Four fiber specimens were created: no retting, minimal retting, moderate retting, and full retting. Fiber characterization tests: strength, elongation, diameter, metal content, wax content, and $\mathrm{pH}$ were conducted with significant differences between fibers. Thermosetting vinyl ester resin was used to produce composite panels via vacuum-assisted infusion. Composite performance was evaluated using fiber bundle pull-out, tensile, impact, and interlaminar shear tests. Composite tests indicate that composite panels are largely unchanged among fiber samples. Variation in composite performance might not be realized due to poor interfacial bonding being of larger impact than the more subtle changes incurred by the enzyme treatment.
\end{abstract}

\section{Introduction}

In Canada, flax is grown for its seed with the potential to produce composites from the residual straw. In 2007-2008, there were 524,068 ha of flax grown in Canada [1] making it a widely available future composite feedstock. Retting is required for the successful extraction of high-quality natural fibers $[2,3]$. Retting involves the breakdown of the bonds between the constituent layers of the stem through the removal of pectin and hemicelluloses that binds the layers together [4]. Dew-retting, a process historically used in Europe, is not a viable method to use across Canada in a cold and dry climate. Historically, in Canada, dew-retted flax does not produce high-quality fibers due to the lack of moisture and warm temperatures that would promote colonization of indigenous soil microorganisms and subsequent plant cell wall degradation. Enzyme-retting has been explored as an option that could be used in Canada and other parts of the world that would not only eliminate the reliance on favorable weather conditions, but also allow the industry to produce more consistent and high-quality fibers without the risks associated with uncontrolled natural retting.

Fiber quality differences between enzyme- or dew-retted fibers and unretted fibers are evident with their subsequent applications significantly diverse [5]. The advantages of enzyme retting are offset by the additional costs and requirements of incorporating enzymes into a production environment that would include energy costs for drying, enzymes for retting, chemicals for maintaining processing conditions, and wastewater handling systems. Currently, there are no turn-key enzyme-retting systems available. Research is required to develop specialized enzyme-retting and mechanical equipment that improve fiber quality via enzyme retting. Previous research by Akin et al. [6], Foulk et al. [5], Rho et al. [7], and Sharma et al. [8] have evaluated enzyme retting using innovative and commercial pectate lyase and chelators to characterize fibers. Nevertheless, it should be noted that retting alone is not sufficient to separate fibers from the straw and some mechanical processing is required, but the effort needed to perform the mechanical 
processing is significantly reduced on properly retted stalks. Either dew or enzyme retting must be integrated with mechanical processing for composite feedstock.

Vacuum-assisted resin transfer molding (VARTM) is a thermoset molding technique that has lower tooling and equipment costs relative to other composite processes. As the biofiber commercial industry is still in development in North America, the supply of high-quality biofibers may be insufficient in the short term to support adoption into highvolume applications, such as compression molding, in the automotive industry. The lower part quantity produced by VARTM and interest from industry to use biocomposites in their products to achieve weight savings and greener parts provides opportunities for biofiber and biocomposite commercialization. The resins that are used in VARTM processes are usually low viscosity, room temperature curing polymers. For flax fiber reinforced composites, the resistance to moisture dictates the service life of the composites. Vinyl ester offers better resistance to moisture and hydrolytic attack than polyesters, which is because of fewer ester groups in the vinyl ester structure. These ester groups are readily hydrolyzed, leading to a significant moisture uptake in the cured composites. Moreover, the cost of vinyl ester is much lower than epoxy and commonly used in VARTM.

In a biocomposite, the performances of the natural fibers are affected by more than the amount of core material present (added) in the resin. Potential factors that may influence composite properties include fiber elongation, wax content, fiber thickness, fiber strength, cellulose content, and crystallinity (compatibilizer and water content). Foulk et al. [9] indicate that density and fiber thickness are positively correlated to interfacial adhesion while calcium, magnesium, bacteria, and wax negatively correlated with interfacial adhesion. Mechanical processing may improve the properties of the processed fibers, but there is the potential that retting, which removes most of the natural biopolymers bonding the fibers together, may improve the performance of the fibers in ways that cannot be solely achieved in a mechanical process. Foulk et al. [10] observed high-density polyethylene composites that contained enzyme-retted fibers behaved differently than composites that contained dew-retted fibers. The objective of this paper was to determine if composite performance improvements were possible through the use of a biotreatment using pectinase (i.e., an alkaline pectate lyase) enzymes. An improvement in performance could demonstrate the potential uses of enzymes to treat natural fibers for biocomposites that would reduce energy costs, reduce processing costs, maintain quality, and create uniform fibers of known quality (or specific quality attributes) from crop to crop.

\section{Materials}

2.1. Fibers and Decortication. Bethune, a common flax variety representing $60 \%$ of the flax grown in Canada, was collected from Saskatchewan, Canada. The seed was removed using a stripper header, and the stalks were pulled out of the ground and left in the field for several weeks to dry.
Some retting occurred in the field before collection, but the degree of ret was minor and the unretted stalks were collected by hand to prevent damage from baling for indoor storage. Samples of unretted stalks were processed by Biolin Research Inc. (Saskatoon, Saskatchewan, Canada) using roller-mill technology to maintain fiber length and reduce mechanical processing to provide coarse fiber bundles as a feedstock for enzyme treatment. Thus, the mechanical decortication was undertaken before applying the enzyme treatment to keep the mechanical processing consistent among retting levels. Small quantities of the stalks were manually processed to remove shive and to produce clean, unretted, long, straight, unidirectional fiber.

2.2. Enzyme Retting. Decorticated fiber samples were enzyme-retted in order to yield a range of characteristically different properties and fiber traits. Four flax samples were examined, ranging in degree of enzyme retting. Samples were enzyme-retted using PL-BRI (i.e., bacterial pectinolytic enzyme with lyase activity (E.C.4.2.2.2.)) produced in Canada at the Biotechnology Research Institute, National Research Council [11]. The enzyme-treated fibers were produced using four $50-\mathrm{L}$ lab-scale reactors and subjected to treatment as indicated in Table 1 and Figure 1. Four fiber specimens were created showing different levels of ret: no retting $(0 \mathrm{~h})$, minimal retting $(10 \mathrm{~h})$, moderate retting $(22 \mathrm{~h})$, and full retting $(46 \mathrm{~h})$. Fiber samples were thoroughly rinsed to prevent additional retting from occurring after the controlled exposure time. The control, unretted fibers were subjected to the same rinsing, and water soak cycle to ensure handling and removal of contaminants through washing remained consistent between the samples. During the retting and rinsing process, the fibers were handled in a manner to reduce entanglement and maintain their unidirectional and parallel orientation.

2.3. Composite Formation. The resin chosen for this study was a promoted, nonthixed modified vinyl ester resin, trade name Hydropel R037-YDF-40 (AOC LLC., Collierville, Tenn, USA). Hydropel is a low-viscosity resin for use in resin infusion processes. Vinyl ester was chosen because it is a common, inexpensive, and moderate performance resin that is utilized to a large extent in glass fiber composite components. With flax fiber being sought as an economic alternative to lower end synthetic fibers such as glass, it is important that studies of interfacial performance be performed using a resin that holds a strong potential for being used, rather than seek a higher end epoxy system which may provide better performance, but at a cost that would be impractical for the vacuum-assisted resin transfer molding industry that is being targeted.

\section{Methodology}

3.1. Fiber Measurements. A series of tests were conducted to determine the quality of the enzyme-retted flax fibers. Fiber measurements suspected of having a direct influence on the interfacial bonding between flax and resin matrix 
TABle 1: Treatments utilized in enzyme-retting flax fibers.

\begin{tabular}{|c|c|c|c|c|c|}
\hline $\begin{array}{l}\text { Enzyme and buffer } \\
\text { solution exposure } \\
\text { (h) }\end{array}$ & $\begin{array}{l}\text { Chelator used } \\
\text { (h) }\end{array}$ & Rinse & $\begin{array}{l}\text { Soak treatment } \\
\text { (h) }\end{array}$ & Degree of ret & $\begin{array}{l}\text { Total exposure time } \\
\text { (h) }\end{array}$ \\
\hline 0 & None & \multirow{4}{*}{ Warm tap water } & 48 (buffer solution) & None & \multirow{4}{*}{48} \\
\hline 10 & 2 & & 36 (tap water) & Minimal & \\
\hline 22 & 2 & & 24 (tap water) & Moderate & \\
\hline 46 & 2 & & None & Fully & \\
\hline
\end{tabular}

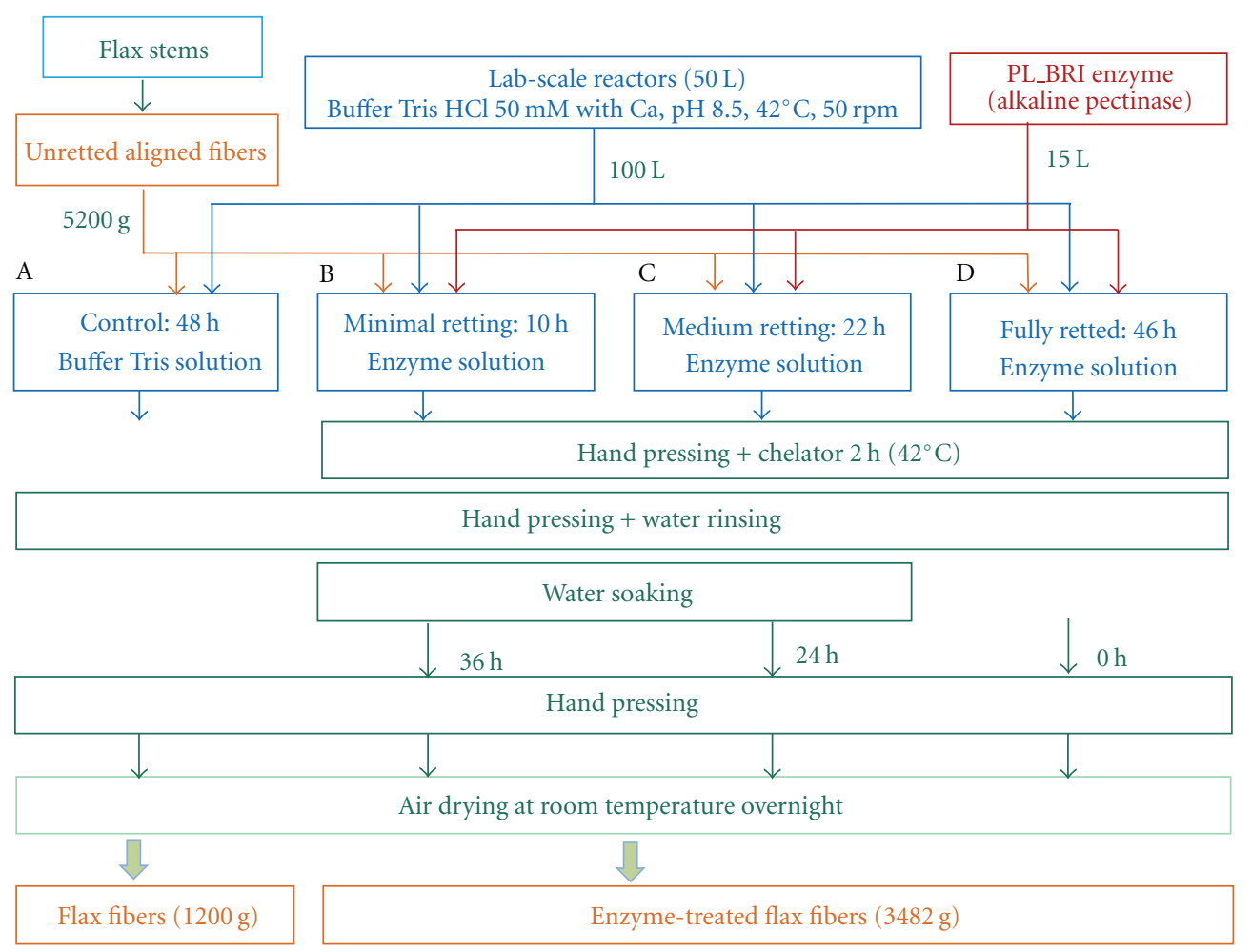

FIgURE 1: Enzyme treatment process.

included fiber wax levels, and metal content was determined according to Foulk et al. [12]. Physical properties of the fibers were determined that could impact the composites load-bearing characteristics including fiber fineness, thickness, strength, and elongation. Fineness measurements were conducted according to ASTM International [13]. Image analysis of fiber thickness was subsequently determined, using Fibreshape version 5.2 image analysis software [14]. Mean fiber bundle strength and elongation were determined using the Stelometer test [15] with measurements measured in force per unit length $(\mathrm{g} / \mathrm{tex})$ and \% elongation.

3.2. Pullout. The fiber pullout method was chosen due to its use and relevance in characterizing the fiber-matrix interaction, as detailed in a previous study by Foulk et al. [9]. As detailed by Foulk et al. [9], fibers were collected from each sample set, with 15 fiber bundles being created from each in order to ensure statistical minimums are met. Testing was performed using an Instron model 5567 load frame
(Norwood, Mass, USA) with a $2 \mathrm{kN}$ load cell, in displacement control at a rate of $0.5 \mathrm{~mm} / \mathrm{min}$. As detailed by Foulk et al. [9], microscopy was used to determine the interfacial area of the pulled fiber bundle. This data, along with the known impregnation depth, was then used to determine the total contact area between the fibers and matrix. Fiber bundle pullout involves embedding fibers into resin at a known depths and measuring the force needed to pull them out of the resin, as opposed to breaking the fibers. It is a controversial test in that the number of specimens needed to legitimately represent a sample set, due to variations inherent in natural products, can be prohibitive to fulfill. Furthermore, a small group of individual fibers (i.e., bundle) is not indicative of a composite's behavior as a whole, as the interactions of fibers and their stepped failure is not fully accounted for. Unfortunately, there is not a direct method of testing interfacial bond strength, and as such fiber pullout remains one of the few ways to try and assess interfacial behavior. 
3.3. Interlaminar Shear Strength (ILSS). The interlaminar shear strength test was chosen due to its use and relevance in characterizing the interfacial strength between fibers and resin, as detailed by Foulk et al. [9]. ILSS testing is less arduous to perform than the fiber bundle pullout due to specimen preparation. In addition, it is a better representative of actual composite performance parameters than fiber bundle pullout. As detailed by Foulk et al. [9], a modified vacuum-assisted resin transfer molding (VARTM) process was implemented using a caul plate. Since failure in ILSS testing should be by shear and not through compressive or tensile yield, the short beam strength [16] can be directly related to the interfacial bonding strength of the fibers and matrix. ILSS testing involves testing of the whole composite and thus reduces the scatter caused by individual or small bundle fiber testing in fiber pullout. The test method involves a three-point bend configuration on a short span. The bend causes the stress to manifest in shear along the interface. The strength of the interface bond is not the only mechanism that will resist the shear, but correlations exist between interface strength and interlaminar shear strength.

3.4. Tensile Strength. Tensile strength was chosen to evaluate the reinforcing value of the fibers in a tensile load condition. Tensile testing was performed on a 5-specimen sample set using an Instron model 5567 load frame (Norwood, Mass, USA) [17]. The speed of the cross-head was $1 \mathrm{~mm} / \mathrm{min}$. Each test was performed until tensile failure occurred. The maximum load was recorded, and the specific tensile strength was calculated for each sample set.

3.5. Impact Strength. In studies by Alcock and Boyko [18] and Evenson [19], the natural fiber panels performed poorly in impact as compared to traditional glass panels or marginally better than resin only panels. It was of interest to see if a discernable difference in impact properties could be seen between the different enzyme treatments. Two different methods of impact testing were conducted. The first was an unnotched test [20] with a modification of the impact surface being on the flat of the coupon rather than the side/edge. This configuration better approximated the type of impact the panel would likely receive in service. The second test was a notched impact [21] which was found in a previous study [19] to reduce scatter between coupons over that of unnotched testing and selected to make differences in performance between the fibres more discernable. The panels for impact testing were manufactured using a vacuumassisted infusion process and an aluminum upper and lower mould. Fibre volume loading was controlled to target $20 \%$. The resin was catalyzed with a MEKP catalyst, L50A, at $2 \%$. Both tests used a Model BLI Izod Impact Testing Machine and a $2 \mathrm{ft}$-lbs hammer. Neat resin specimens were tested for comparison.

\section{Results and Discussion}

4.1. Fiber Physical Properties. Composites require fibers to be used as a tensile reinforcing medium, making fiber
TABle 2: Physical properties of enzyme-retted flax fibers*.

\begin{tabular}{lccc}
\hline \multirow{2}{*}{$\begin{array}{c}\text { Enzyme exposure } \\
(\mathrm{h})\end{array}$} & $\begin{array}{c}\text { Strength } \\
(\mathrm{g} / \text { tex })\end{array}$ & $\begin{array}{c}\text { Elongation } \\
(\%)\end{array}$ & $\begin{array}{c}\text { Image analysis } \\
\text { Fiber thickness } \\
(\mu \mathrm{m})\end{array}$ \\
\hline 0 & $46.48 \mathrm{a}$ & $0.67 \mathrm{c}$ & $37.9 \mathrm{a}$ \\
10 & $43.47 \mathrm{a}$ & $1.42 \mathrm{a}$ & $28.0 \mathrm{c}$ \\
22 & $37.68 \mathrm{a}$ & $0.92 \mathrm{~b}, \mathrm{c}$ & $32.5 \mathrm{~b}$ \\
46 & $44.12 \mathrm{a}$ & $1.25 \mathrm{a}, \mathrm{b}$ & $27.0 \mathrm{c}$ \\
\hline
\end{tabular}

${ }^{*}$ Values followed by different letters within columns are significantly different at $P \leq 0.05$.

tensile strength one of the key components in material selection for composite design. Knowledge of the fiber strength and stiffness is critical in determining if a composite is reaching its full potential or hindered by other factors such as poor interfacial bonding. The Stelometer strength results are displayed in Table 2 with fiber strength not decreasing with increased enzyme-retting levels. Indigenous microorganisms may lead to reduced fiber strengths that degrade the cellulose in traditional dew retting. These fibers have been enzyme-retted without degrading the cellulose and reducing its strength. The elongation of these fibers appears to increase with increased enzyme exposure time. The elongation trend is consistent except for the $10 \mathrm{~h}$ enzyme sample where elongation is higher than expected. The sample may not have been exposed to the enzyme long enough to produce reliable retting, or short enzyme exposure times may generate inconsistent fiber diameters as a result of uneven fiber treatment.

The fiber dimension, mean diameter, is considered one of the contributing factors of fiber performance in a composite. Fibers with a small aspect ratio traditionally demonstrate improved performance due to a greater surface to volume ratio for bonding, reduced net narrowing effect when stretched, and increased likelihood of being flawless over the length of the fiber. Thermoplastic and biofiber composite performance has previously been influenced by fiber diameter $[9,22]$. As expected, using image analysis software, fiber thicknesses were found to decrease with increasing enzyme exposure (Table 2). Scanning electron microscope images (SEM) were used to verify the results of the Fibreshape analysis as shown in Figure 2. Visual review of the SEM images demonstrates fiber fineness decreasing with the increases of enzyme exposure time. In addition to reduced fiber diameters, the surface appears smoother in the $24 \mathrm{~h}$ and $48 \mathrm{~h}$ fiber specimens as compared to the $0 \mathrm{~h}$ fiber specimen.

4.2. Fiber Chemical Properties. Based on Foulk et al. [9], the metal content, specifically calcium and magnesium, correlated to reduced fiber-matrix interfacial interactions with increasing levels of calcium and magnesium. Metal analysis conducted on these fiber samples measured calcium, magnesium, potassium, zinc, iron, and sodium levels as parts per million following the test procedures in Foulk et al. [12]. The results of the analysis are displayed in Table 3. 


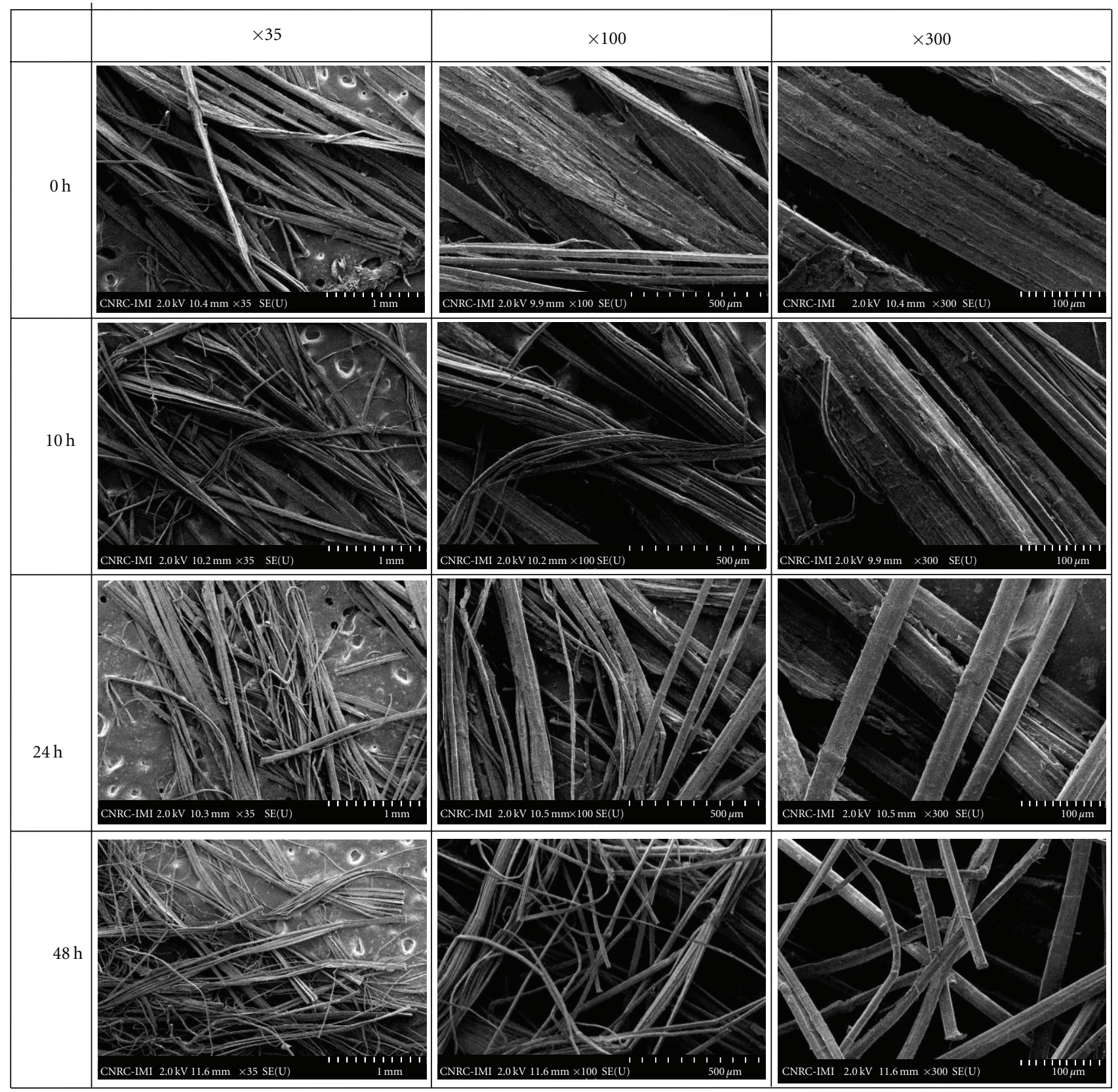

FIgURE 2: SEM images of fiber samples at different magnifications.

Calcium and magnesium levels indicated a decreasing trend with increasing enzyme exposure. Calcium and magnesium are located in the pectin that binds together cellulose fibers with enzyme retting removing this pectin. The $0 \mathrm{~h}$ fiber sample was exposed to calcium in the buffer solution, but was not exposed to the chelator. Exposure without using the chelator may have increased the calcium level higher than the untreated sample. The sodium and potassium levels demonstrated a positive trend with exposure to the enzymes. The zinc levels confirmed an inverse trend with increasing exposure, but the levels were very small with high standard deviations. The iron levels demonstrated no trend between enzyme-retting treatments.
Wax is an important component of the noncellulosic plant materials in flax. The major portion of the wax, along with cutin and aromatics, forms the stem surface barrier. Flax fibers contain a portion of wax, often found on the outside of the fibers in the portion called the cuticle. The wax is not chemically bonded to the fiber; however, it can still be difficult to remove, especially from mature or seed flax stems [23]. Wax was found in Foulk et al. [9] to be a detrimental quality on the performance of the composite due to its potential to prevent the resin from bonding with the fibers. The wax levels of the fibers showed an inverse trend with increasing enzyme exposure in Table 3. Wax located in the cuticle is removed in the enzyme-retting process. 
TABLE 3: Chemical properties of enzyme-retted flax fibers*.

\begin{tabular}{lccccccc}
\hline $\begin{array}{l}\text { Enzyme exposure } \\
(\mathrm{h})\end{array}$ & Wax & \multicolumn{5}{c}{ Metal content (ppm) } \\
\hline 0 & $(\%)$ & $\mathrm{Na}$ & $\mathrm{Ca}$ & $\mathrm{K}$ & $\mathrm{Mg}$ & $\mathrm{Zn}$ \\
10 & $1.38 \mathrm{~b}$ & $11.92 \mathrm{~b}, \mathrm{c}$ & $160.87 \mathrm{a}$ & $8.81 \mathrm{~b}$ & $29.31 \mathrm{a}$ & $0.66 \mathrm{a}$ & $4.44 \mathrm{~b}$ \\
22 & $1.49 \mathrm{a}$ & $6.96 \mathrm{c}$ & $63.98 \mathrm{~b}$ & $7.35 \mathrm{~b}$ & $14.08 \mathrm{~b}$ & $0.76 \mathrm{a}$ & $2.97 \mathrm{c}$ \\
46 & $1.32 \mathrm{~b}$ & $30.30 \mathrm{~b}$ & $48.02 \mathrm{c}$ & $10.30 \mathrm{~b}$ & $11.95 \mathrm{~b}$ & $0.45 \mathrm{a}$ & $6.47 \mathrm{a}$ \\
\hline
\end{tabular}

${ }^{*}$ Values followed by different letters within columns are significantly different at $P \leq 0.05$.

TABLE 4: Interface and tensile strengths of enzyme-retted flax fiber composites*.

\begin{tabular}{lccccc}
\hline $\begin{array}{l}\text { Enzyme exposure } \\
(\mathrm{h})\end{array}$ & $\begin{array}{c}\text { Fiber volume fraction } \\
(\%)\end{array}$ & $\begin{array}{c}\text { Pullout } \\
(\mathrm{MPa})\end{array}$ & $\begin{array}{c}\text { Specific ILSS } \\
(\mathrm{MPa})\end{array}$ & $\begin{array}{c}\text { Specific tensile modulus } \\
\mathrm{GPa} /\left(\mathrm{g} / \mathrm{cm}^{3}\right)\end{array}$ & $\begin{array}{c}\text { Specific tensile strength } \\
\mathrm{MPa} /\left(\mathrm{g} / \mathrm{cm}^{3}\right)\end{array}$ \\
\hline 0 & 38 & $12.21 \mathrm{~b}$ & $9.45 \mathrm{~b}$ & $2.34 \mathrm{a}$ & $54.66 \mathrm{~b}$ \\
10 & 39 & $17.07 \mathrm{a}$ & $11.32 \mathrm{a}$ & $2.07 \mathrm{a}$ & $48.54 \mathrm{~b}$ \\
22 & 34 & $15.74 \mathrm{a}$ & $9.57 \mathrm{~b}$ & $2.18 \mathrm{a}$ & $71.46 \mathrm{a}$ \\
46 & 37 & $12.53 \mathrm{~b}$ & $10.36 \mathrm{a}, \mathrm{b}$ & $2.76 \mathrm{a}$ & $70.91 \mathrm{a}$ \\
\hline
\end{tabular}

*Values followed by different letters within columns are significantly different at $P \leq 0.05$.

4.3. Composite Properties. Interface testing assesses the ability of fiber to bond to the matrix. The interfacial bonding could be affected by a number of surface conditions that could be physical or chemical in nature. Two test methods were utilized to indirectly assess the interfacial properties: fiber bundle pullout and interlaminar shear strength (ILSS). Pullout strengths of the four samples were higher than the ILSS strengths, which might have occurred because the fiber bundles for pullout were carefully selected and methodically aligned. Trends for both interface tests demonstrate no relationships between enzyme retting and interface strength (Table 4). Composite tests indicate that composite panels are largely unchanged among fiber samples. Variation in composite performance might not be realized due to poor interfacial bonding being of larger impact than the more subtle changes incurred by enzymes. In addition, the smoother fiber surface created by longer enzyme retting reduces the mechanical interlocking between fiber and matrix which could decrease interfacial bonding. The $10 \mathrm{~h}$ fiber composite sample demonstrated the largest fiber volume fraction, ILSS, and pullout strength, while $0 \mathrm{~h}$ fiber composite sample demonstrated the lowest ILSS and pullout strength. This would indicate that at least some level of enzyme retting leads to improvement in interfacial properties rather than none at all.

Figures 3 and 4 provide representative SEM images of fracture sights within the composite samples tested under ILSS without any enzyme retting and with $46 \mathrm{~h}$ of enzyme retting, respectively. As shown in Figure 3, very little matrix is attached to the fiber surface, resulting in clean, large cavitations which indicate minimal interfacial bonding without enzyme treatment. However, in Figure 4, it is shown that matrix adhesion to the fiber surface was improved by the increase in matrix fractions adhered along the fiber surface and matrix failure outside of the fiber/matrix interface observed. All levels of enzyme retting were shown to improve interfacial adhesion of the matrix to fibers over the unretted

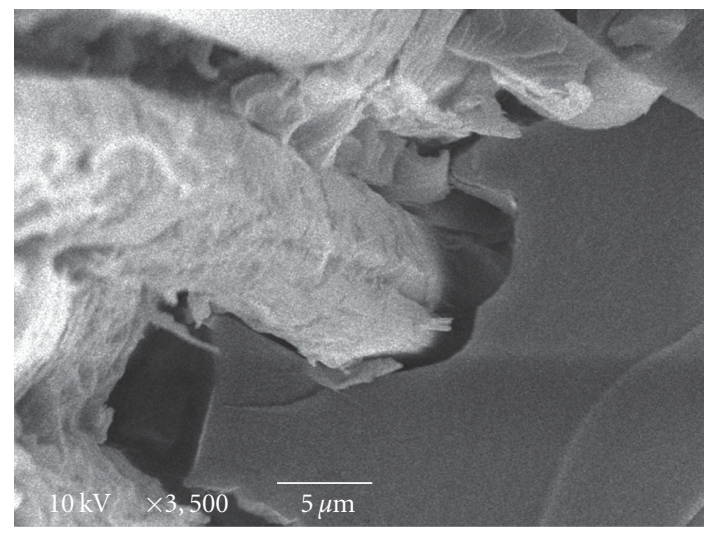

FIGURE 3: A representative SEM image of a failed composite sample with unretted $(0 \mathrm{~h})$ fibers.

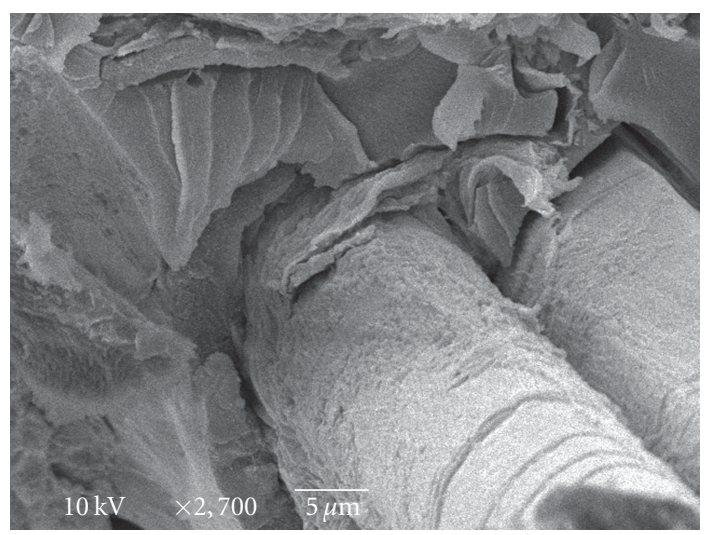

FIGURE 4: A representative SEM image of a failed composite sample with retted $(46 \mathrm{~h})$ fibers. 
TABLE 5: Notched and unnotched impact strengths of enzyme-retted flax fiber composites*.

\begin{tabular}{|c|c|c|c|}
\hline Sample & Volume fraction & $\begin{array}{l}\text { Notched impact specific } \\
\text { strength }\end{array}$ & $\begin{array}{l}\text { Modified Unnotched } \\
\text { specific impact strength }\end{array}$ \\
\hline (h) & (Impact \%) & $\left(\mathrm{kJ} / \mathrm{m}^{2 *} \mathrm{~cm}^{3} / \mathrm{g}\right)$ & $\left(\mathrm{kJ} / \mathrm{m}^{2 *} \mathrm{~cm}^{3} / \mathrm{g}\right)$ \\
\hline 0 & 21 & $9.9 \mathrm{a}$ & $8.8 \mathrm{a}, \mathrm{b}$ \\
\hline 10 & 20 & $9.2 \mathrm{a}, \mathrm{b}$ & $9.7 \mathrm{a}, \mathrm{b}$ \\
\hline 22 & 22 & $8.0 \mathrm{~b}$ & $8.3 \mathrm{~b}$ \\
\hline 46 & 19 & $9.7 \mathrm{a}$ & $10.1 \mathrm{a}$ \\
\hline Neat Resin & N.A. & $1.0 \mathrm{c}$ & $4.0 \mathrm{c}$ \\
\hline
\end{tabular}

${ }^{*}$ Values followed by different letters within columns are significantly different at $P \leq 0.05$.

TABle 6: Pearson's correlation between enzyme exposure, interfacial bond strength, impact strength and constituent content plus fiber characteristic measurements.

\begin{tabular}{|c|c|c|c|c|c|c|c|}
\hline Trait & $\begin{array}{l}\text { Enzyme } \\
\text { exposure }\end{array}$ & $\begin{array}{l}\text { Notched impact } \\
\text { specific strength }\end{array}$ & $\begin{array}{c}\text { Unnotched } \\
\text { impact specific } \\
\text { strength }\end{array}$ & Pullout & Specific ILSS & $\begin{array}{l}\text { Specific tensile } \\
\text { modulus }\end{array}$ & $\begin{array}{l}\text { Specific tensile } \\
\text { strength }\end{array}$ \\
\hline Enzyme exposure & na & 0.047 & 0.336 & -0.086 & 0.150 & 0.354 & 0.612 \\
\hline Strength (g/tex) & -0.242 & 0.415 & 0.157 & -0.202 & 0.088 & -0.258 & -0.200 \\
\hline Elongation (\%) & 0.321 & -0.236 & -0.261 & 0.285 & 0.599 & -0.006 & 0.136 \\
\hline $\mathrm{Ca}(\mathrm{ppm})$ & -0.847 & 0.322 & -0.021 & -0.415 & -0.251 & -0.149 & -0.428 \\
\hline $\mathrm{Mg}(\mathrm{ppm})$ & -0.741 & 0.377 & 0.205 & -0.426 & -0.050 & 0.096 & -0.328 \\
\hline $\mathrm{Na}(\mathrm{ppm})$ & 0.898 & 0.244 & 0.114 & -0.045 & -0.318 & 0.210 & 0.694 \\
\hline $\mathrm{K}(\mathrm{ppm})$ & 0.861 & 0.452 & 0.270 & 0.006 & -0.303 & 0.260 & 0.572 \\
\hline $\mathrm{Fe}(\mathrm{ppm})$ & -0.089 & -0.412 & -0.656 & 0.504 & -0.349 & -0.057 & 0.509 \\
\hline $\mathrm{Zn}(\mathrm{ppm})$ & -0.300 & -0.520 & 0.071 & -0.375 & 0.661 & -0.342 & -0.472 \\
\hline Wax content $(\%)$ & -0.821 & -0.370 & -0.283 & 0.347 & 0.317 & 0.353 & 0.066 \\
\hline
\end{tabular}

fibers. However, qualifying adhesion differences via SEM images of the fractures surfaces between enzyme retting levels of $10 \mathrm{~h}, 22 \mathrm{~h}$, and $46 \mathrm{~h}$ were not possible in this study but are recommended for future studies. Enzyme retting was found in $\mathrm{Hu}$ et al. [24] to be potentially advantageous in composite formation.

The specific tensile strength of the $22 \mathrm{~h}$ and $46 \mathrm{~h}$ fiber composite sample performed better than the $0 \mathrm{~h}$ and $10 \mathrm{~h}$ fiber composite sample (Table 4). Sample $10 \mathrm{~h}$ demonstrates the lowest in tensile strength and specific tensile strength. Minor trends exist for specific tensile modulus and specific tensile strength with specific tensile values increasing with enzyme exposure. However, in plotting tensile strength against the fiber volume fractions of the composites, an inverse relationship exists between strength and volume fraction. Variation in tensile strength might not be realized due to poor interfacial bonding and impact of fiber volume fraction which is difficult to control sample to sample using resin infusion methods.

In evaluating notched impact testing the performance of the biofiber, samples were reasonably consistent where neat resin had a significant reduction in impact properties (Table 5). Unnotched impact testing demonstrated that the performance of the biofiber samples slightly increased with enzyme exposure and the neat resin had a significant reduction in impact properties. The enzyme exposure of $46 \mathrm{~h}$ demonstrated better performance over the other enzyme exposure treatments. The fiber reinforcement improved both impact properties of the composite over the neat resin. Increasing volume fraction appears to have a detrimental trend to impact performance of the unnotched samples+ but was not correlated with the notched test. The neat resin performed poorly in comparison to the fiber reinforced panels, indicating the decreasing performance trend must have an optimum fiber loading point between the 19\% fiber loading and $0 \%$.

4.4. Correlations. A Pearson's correlation study was performed to determine if linear trends exist between flax fiber characteristics, enzyme exposure, and composite performance characteristics. Several correlations between enzyme exposure and physical properties (\%wax, elongation, calcium, magnesium, sodium, and potassium) were found which indicate the enzyme exposure was influential. Table 6 indicates a summary of the properties tested and the correlations found. The composite interfacial test results (pullout and specific ILSS) did not indicate a correlation between increasing enzyme exposure and performance of the composite panels. Interfacial test results indicate negative correlations with several metals, while \%wax is positively correlated to interfacial strength. Results of testing appear to demonstrate that composite performance is largely unchanged, which is not as desirable as positive correlation, but not seeing a detrimental effect is still valuable. Specific 
tensile modulus, specific tensile strength, and unnotched impact specific strength demonstrate positive correlations, indicating that fibers that have been exposed to these enzymes for longer periods of time create stronger composites. Fiber testing results demonstrated significant differences between fibers, however, it is possible that variation in composite performance might not be completely realized due to poor interfacial bonding being of larger impact than the more subtle changes incurred by exposure to the enzymes. Besides enzyme exposure time, physical factors (e.g., nonhomogeneous fiber distribution or fiber bundles not finely divided into ultimate fibers via mechanical processes) may have had an impact on composite performance.

\section{Conclusions}

Fiber strength is one of the key factors in composite formation, and it did not decrease with increased enzyme-retting levels. The pectinase enzyme PL-BRI does not degrade the cellulose and reduce its fiber strength. Another contributing factor of a fibers performance in a composite is its diameter that was found to decrease via image analysis and SEM with increasing enzyme exposure. The pectinase enzyme PL-BRI removes pectin that separates the fiber bundles and concurrently creates smoother fibers. Calcium and magnesium found in the pectin bind together cellulose fibers with enzyme retting removing these metals with increasing enzyme exposure. Wax in the cuticle is detached via enzyme retting and decreases with enzyme exposure. Trends for fiber bundle pullout and ILSS interface tests do not demonstrate relationships between enzyme retting and interface strength. Composite tests indicate that composite panels are largely unchanged among fiber samples. No consistent trend is apparent in the specific tensile modulus, tensile strength, or impact testing (unnotched test and notched impact). Performances of biocomposite samples were reasonably consistent where neat resin had a significant reduction in properties. Longer enzyme exposure appears to demonstrate improved composite performance. Fiber reinforcement did improve the impact properties of the composite over the neat resin. Variation in composite performance might not be realized due to poor interfacial bonding being of larger impact than the more subtle changes incurred by enzymes. Enzyme retting via the pectinase PL-BRI is capable of producing consistent high-strength renewable fibers with variable fineness values for use in novel resins developed for natural fiber agricultural feedstock composites.

\section{Disclaimer}

Mention of a trade name, proprietary product, or specific equipment does not constitute a guarantee or warranty by the US Department of Agriculture; information is for information purposes only and does not imply approval of a product to the exclusion of others that may be suitable.

\section{Acknowledgments}

The authors gratefully acknowledge and appreciate the help provided by producers, processors, and others including Biolin Research Inc. They gratefully acknowledge Robert Harrison and Linda James from USDA ARS CQRS for assisting with testing and setup. They gratefully acknowledge Katie Schalkoff from Clemson University along with Michael Fuqua from North Dakota State University for their assistance. The authors also gratefully acknowledge the work of Dr. Nereida Coello, who performed the enzyme treatment with the technical assistance of Marie-Josée Lorrain at NRCBRI. Partial financial support for the work conducted was received from Agriculture and Agri-Food Canada through the Agriculture Bioproducts Innovation Program.

\section{References}

[1] Statistics Canada, "Cereal and oilseeds review," Catalogue 22007-X, Minister of Industry, Canada, 2009.

[2] D. E. Akin, G. Henriksson, J. D. Evans, A. P. S. Adamsen, J. A. Foulk, and R. B. Dodd, "Progress in enzyme-retting of flax," Journal of Natural Fibers, vol. 1, no. 1, pp. 21-47, 2004.

[3] R. Kozlowski, J. Batog, W. Konczewicz et al., "Enzymes in bast fibrous plant processing," Biotechnology Letters, vol. 28, no. 10, pp. 761-765, 2006.

[4] C. Van Sumere, "Retting of flaw with special reference to enzyme-retting," in The Biology and Processing of Flax, $\mathrm{H}$. Sharma and C. Van Sumere, Eds., pp. 157-198, M Publications, Belfast, Northern Ireland, 1992.

[5] J. A. Foulk, D. E. Akin, and R. B. Dodd, "Influence of pectinolytic enzymes on retting effectiveness and resultant fiber properties," BioResources, vol. 3, no. 1, pp. 155-169, 2008.

[6] D. E. Akin, B. Condon, M. Sohn, J. A. Foulk, R. B. Dodd, and L. L. Rigsby, "Optimization for enzyme-retting of flax with pectate lyase," Industrial Crops and Products, vol. 25, no. 2, pp. 136-146, 2007.

[7] D. Rho, J. Yang, M. Lorrain et al., "Processing of flax fibers for biocomposites using a thermostable pectate lyase," in Proceedings of the International Conference on Flax and Other Bast Plants, pp. 201-210, Saskatoon, Saskatchewan, Canada, July 2008.

[8] H. S. Sharma, G. Fauchey, and G. Lyons, "Comparison of physical, chemical, and thermal characteristics of water-, dew, and enzyme-retted flax fibers," Journal of Applied Polymer Science, vol. 74, no. 1, pp. 139-143, 1999.

[9] J. A. Foulk, M. A. Fuqua, C. A. Ulven, and M. M. Alcock, "Flax fibre quality and influence on interfacial properties of composites," International Journal of Sustainable Engineering, vol. 3, no. 1, pp. 17-24, 2010.

[10] J. A. Foulk, W. Y. Chao, D. E. Akin, R. B. Dodd, and P. A. Layton, "Enzyme-retted flax fiber and recycled polyethylene composites," Journal of Polymers and the Environment, vol. 12, no. 3, pp. 165-171, 2004.

[11] Z. Xiao, J. Boyd, S. Grosse, M. Beauchemin, E. Coupe, and P. C. K. Lau, "Mining Xanthomonas and Streptomyces genomes for new pectinase-encoding sequences and their heterologous expression in Escherichia coli," Applied Microbiology and Biotechnology, vol. 78, no. 6, pp. 973-981, 2008.

[12] J. Foulk, G. Gamble, H. Senter, and W. Meredith, "Commercial cotton variety spinning study descriptive statistics and distributions of cotton fiber and yarn," in Proceedings of the Beltwide 
Cotton Conferences, National Cotton Council America, New Orleans, La, USA, January 2007.

[13] ASTM International, "Standard test method for assessing clean flax fiber fineness (D7025)," in Annual Book of Standards, Section 7, Textiles, ASTM, West Conshohocken, Pa, USA, 2005.

[14] H. Schmid and J. Müssig, "Image scanning for measurement of cotton fiber width," in Proceedings of the International Textile Manufactures Federation, (ITMF '02), International Committee on Cotton Testing Methods, Bremen, Germany, month year.

[15] ASTM International, "Standard test method for breaking strength and elongation of cotton fibers (flat bundle method) (D1445)," in Annual Book of Standards, Section 7, Textiles, ASTM, West Conshohocken, Pa, USA, 2005.

[16] ASTM International, "Standard test method for hort-beam strength of polymer matrix composite materials and their laminates (D2344)," in Annual Book of Standards, Section 15, Textiles, ASTM, West Conshohocken, Pa, USA, 2006.

[17] ASTM International, "Standard test method for tensile properties of polymer matrix composite materials (D3039)," in Annual Book of Standards, Section 15, Plastics, ASTM, West Conshohocken, Pa, USA, 2008.

[18] M. Alcock and S. Boyko, "Flax fiber mat assessment," Report 06-020-03-R01, Composites Innovation Center, Manitoba, Canada, 2007.

[19] N. Evenson, "Comparative analysis of notched versus unnotched impact testing of a natural fiber composite," Report 09-000-06-R01, 2009.

[20] ASTM International, "Standard test method for unnotched cantilever beam impact resistance of plastics (D4812)," in Annual Book of Standards, Section 8, Plastics, ASTM, West Conshohocken, Pa, USA, 2006.

[21] ASTM International, "Standard test method for determining the izod pendulum impact resistance of plastics (D256)," in Annual Book of Standards, Section 8, Plastics, ASTM, West Conshohocken, Pa, USA, 2010.

[22] J. Müssig, M. Karus, and R. Frank, "Bast and leaf fiber composite materials," in Bast and Other Plant Fibers, R. R. Frank, Ed., pp. 352-367, Woodhead Publishing, Cambridge, England, 2005.

[23] D. E. Akin, W. H. Morrison, L. L. Rigsby, and R. B. Dodd, "Plant factors influencing enzyme retting of fiber and seed flax," Journal of Agricultural and Food Chemistry, vol. 49, no. 12, pp. 5778-5784, 2001.

[24] W. Hu, M. Ton-That, J. Denault, D. Rho, J. Yang, and P. Lau, "Influence of retting process on the thermal and mechanical properties of flax-polypropylene composites made of Canadian oilseed flax fibers," in Proceedings of the Polymer Processing Society 26th Annual Meeting, Banff, Canada, July 2010. 

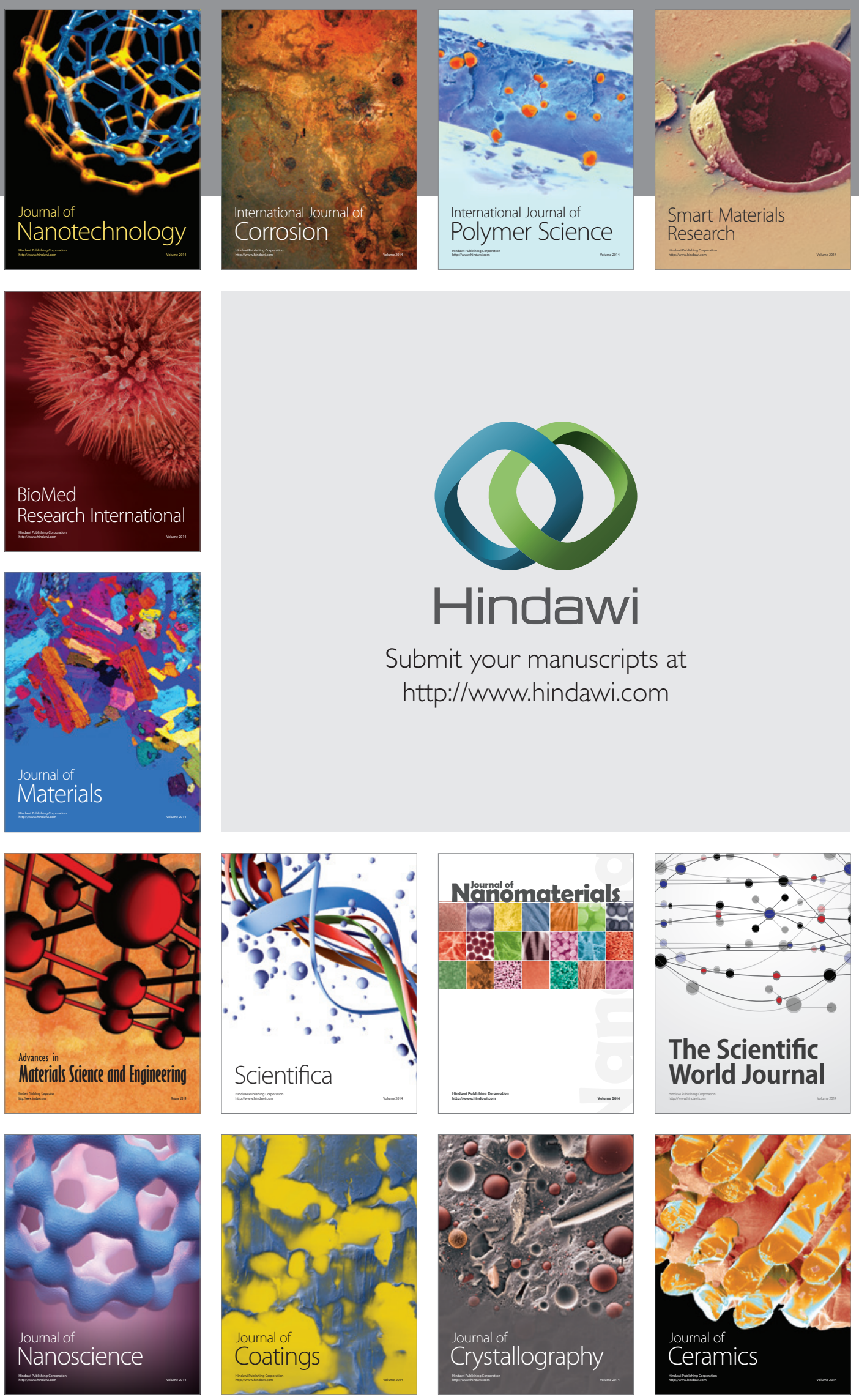

The Scientific World Journal

Submit your manuscripts at

http://www.hindawi.com

\section{World Journal}

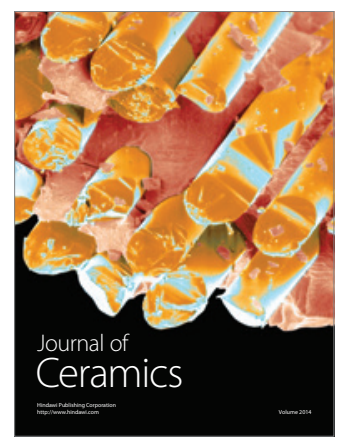

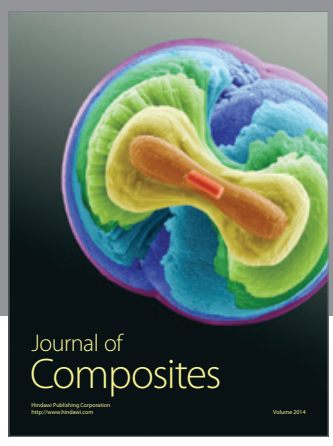
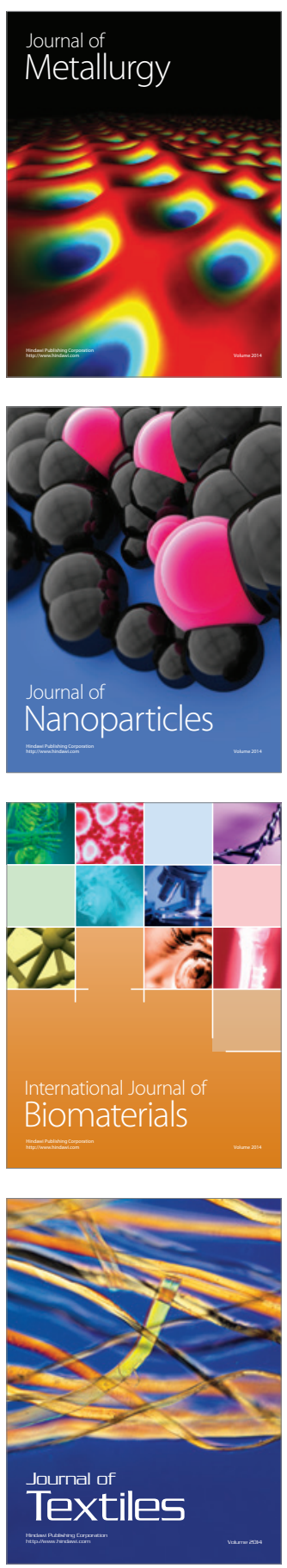